\title{
Seeing the world through the eyes of Andries van Aarde: Radical inclusivity
}

\author{
Author: \\ Glenna S. Jackson ${ }^{1,2}$ \\ Affiliations: \\ ${ }^{1}$ Department of Religion \\ and Philosophy, Otterbein \\ College, United States \\ ${ }^{2}$ Faculty of Theology, \\ University of Pretoria, \\ South Africa \\ Note: \\ Prof. Dr Glenna S. Jackson \\ is participating as research \\ associate in the project \\ 'Biblical Theology and \\ Hermeneutics', directed \\ by Prof. Dr Andries G. van \\ Aarde, honorary professor \\ in the Faculty of Theology \\ at the University of \\ Pretoria, South Africa.

\section{Correspondence to:} \\ Glenna Jackson \\ email: \\ gjackson@otterbein.edu \\ Postal address: \\ 27 South Grove Street, \\ Westerville, $\mathrm{OH} 43081$ - \\ 2004, United States \\ Dates: \\ Received: 26 May 2010 \\ Accepted: 15 June 2010 \\ Published: 07 June 2011 \\ How to cite this article: \\ Jackson, G.S., 2011, \\ 'Seeing the world through \\ the eyes of Andries van \\ Aarde: Radical inclusivity', \\ HTS Teologiese Studies/ \\ Theological Studies 67(1), \\ Art. \#872, 6 pages. DOI: \\ 10.4102/hts.v67i1.872
}

In the article the author reflected on her personal and existential experience of a journey to Egypt, and how this highlights radical inclusivity. The article focused on the issues of the violence of poverty, the history of Coptic Christianity and the role of women within this tradition. The article touched on aspects such as 'women monks', ecclesiastical hierarchy in modern Coptic Christianity, and the ordination of clergy. It also considered the perspective of 'social hierarchy' and 'spiritual or divine hierarchy'.

\section{A tribute to Andries van Aarde}

My association with Prof. Dr Andries G. van Aarde began at the Jesus Seminar in Santa Rosa, California, in the spring of 1996, and continued that summer at the International Society of Biblical Literature Annual Meeting in Dublin, Ireland. I was a relative newcomer to the field as I had been raising a family and teaching and performing as a professional musician until 1992. But our mutual interest in New Testament studies, the Gospel of Matthew in particular, in feminism and in issues related to poverty drew us together at a number of venues, and his generous invitations to me were instrumental in stimulating my teaching and research agendas.

In addition to inviting me to attend and present my work on the story of the Canaanite Woman (Mt 15:21-28) at the Studiorum Novi Testamenti Societas in Bonn, Germany, and Barcelona, Spain, Andries invited me to be a research fellow at the University of Pretoria during the summer and fall of 2000. Lecturing at both the University of Pretoria and Hammanskraal Seminary created a major impact during the first leg of my first visit to the continent of Africa - what a learning experience it was to be a part of two such diverse educational institutions - to say nothing of firsttime safaris with my husband, Gary, that summer, and our first-born, Wendy, that fall. But my most profound memory of travelling with Andries was formed in Egypt and the Sinai Peninsula. I shall discuss two aspects of that trip, both of which are puzzling to me, as well as connections with Andries and his radical inclusivity: the violence of poverty and Coptic Christianity and women.

\section{The violence of poverty}

During the fall semester of 2004, I took a part of my sabbatical leave in Cairo, Egypt, where I lectured at the Evangelical Seminary of Cairo, snooped around Cairo and the surrounding area, and travelled to the Sinai Peninsula. Andries was at the Seminary as a visiting scholar-professor for the entire semester and we once travelled together by bus to the Sinai Peninsula. On the trip, Andries let me know that everyone else on the bus thought I was a prostitute because I was the only female traveller accompanying a man who was obviously not my husband, or a male relative, and I was perfectly willing to engage in conversation with any English-speaking man along the way - even at the bus stops where I looked men in the eye. It was there in Cairo with Andries that I finally was able to articulate the violence of poverty.

I have long been baffled by Luke's Jesus ${ }^{2}$ arguing that the poor are to be blessed and the idea of God's domain belonging to them (6:20). What sense does that make? The poor are not blessed! I have seen poverty in the United States. For example, our third-born, Mandy, works as a paediatrician in clinics that serve migrant workers' families in California and she lives in a community that serves the homeless - there is nothing blessed about those scenarios. ${ }^{3} \mathrm{I}$ have seen even worse poverty on the continent of Africa (cf. Jackson 2004a:81-90, 2004b:239-247, 2008:1-11)

1.Andries van Aarde has written extensively on both of these topics and promotes a circle of praxis related to liberation, peace and justice for all; he, for instance, is the executive director of the NGO To Care Foundation that focuses on poverty alleviation in Africa.

\section{Probably the historical Jesus.}

3.The 'Main Causes of Homelessness', according to Love Loudly, the newsletter published by Dorothy's Place in Salinas, California, are lack of affordable housing; low-paying jobs; mental illness and the lack of needed services or other health issues; substance abuse and the lack of needed services; domestic violence or relationship disintegration; unemployment; poverty; prisoner re-entry; and hospital release of the indigent. 
when shaking hands with people in Malawi who I knew would be dead from starvation within a week and hugging an epileptic acquaintance who died from untreated seizures before I could see him again the next summer. When I was in Vietnam with our son Adam a few years ago, a mother stood in front of us with her dead baby and asked for money to feed her remaining children. And the worst poverty I have seen was in India where I saw torsos (i.e. persons without arms or legs) begging to be fed. Poverty is violent and it is painful. When fourth-born Adam arrived from Vietnam as a starving seven-month-old orphan in 1975, he was in great physical pain and had to be hospitalised for ten days, hooked up to life-giving intravenous devices; starvation is physically violent. He was not blessed! But the strangest kind of poverty I have witnessed was in Cairo, Egypt, at the City of Garbage Pickers. Frankly, I have yet to figure out how any of these people can be considered blessed.

Before I flew to Cairo, I accessed a website where Dr Mamdouh El-Beltagui, Minister of Tourism, had written:

Egypt is the cradle of human civilization: a fact hardly contested among authoritative historians. But Egypt also enjoys a focal geopolitical position, connecting Africa, Asia, and Europe through the Mediterranean Sea. On its land, migrations of people, traditions, philosophies and religious beliefs succeeded each other for thousands of years. Evidence of this succession is still visible in the accumulation of monuments and sites attesting to a uniquely comprehensive cultural heritage. Indeed, one of the phenomena which shaped Egypt's distinctive identity, and explains its pervasive influence on the then known world, was a dynamism that accommodated and reformulated these successive cultures into one homogenous and harmonious Egyptian canvas. Egypt is one civilization woven of many strands, threaded by successive and intertwining eras: the Pharaonic, the Graeco-Roman, the Coptic Christian, and the Islamic eras. Because the Egyptian people are the essential product of the 'harmony in diversity', 'otherness' has become an integral component of their awareness, a basic constituent of their national and cultural identity. This characteristic has yielded one important result: Egypt was, and still is, the land of refuge in the widest sense of the word, a place of tolerance and dialogue for peoples, races, cultures and religion.

(El-Beltagui n.d.)

However, my personal experience of Cairo is quite different from this description of the most positive kind of cosmopolitanism. Indeed, I found myself both agreeing and disagreeing with Dr El-Beltagui's statement and, thanks to Andries, I was about to have the experience of a lifetime.

Whilst at the Seminary, a student by the name of Sharif asked me whether I wanted to visit the City of Garbage Pickers. Having no idea what he was talking about, I said, 'Sure'. And so we arranged a date for later that week. Throughout that week, other students would giggle and say, 'I hear you're going to the City of Garbage Pickers. Be sure to hold your nose!' I would answer that I had changed my share of diapers with four children all under the age of five at one time and, therefore, 'Nothing could bother me'. I was also aware that Sharif was having trouble getting a taxi driver to commit to taking us, but, again, some things just go over my head. I did look for the City of Garbage Pickers in the tour guide, The Lonely Planet, though, and could not find it. However, three of us, Sharif, Andries and I, ventured out one morning. The students seemed overly interested and wondered, as they saw us off, whether I did not need to wear a pair of boots rather than the sandals I was wearing. I thought they were teasing. 'Hmmm', I thought to myself. As we entered the City of Garbage Pickers, which is located in the mountainous caves on the outskirts of Cairo, I was overwhelmed by the sight, sound and stench, and urgently said to Sharif, 'Tell the driver to stop. I have to think about this.' I also had to catch my breath, literally. Sharif told the driver, who communicated only in Arabic, to stop and I quickly thought through my dilemma. To make what seemed like a very long moment short, I decided to go through with the adventure; surely, I could handle for half a day what thousands of people were living in all of the time. Andries seemed to have done his homework and had a much better idea than I as to what we were going to find and was not quite so obviously upset and I was no longer humming.

As we drove into the heart of the city, we got hemmed in by two large garbage trucks and two flatbeds pulled by donkeys, one from each of the four streets leading into the intersection. I have no reason to believe that this was anything but unintentional. At any rate, the taxi driver told Sharif in Arabic that he had had enough and refused to go any further. We could either leave with him, or walk the rest of the way. To make another seemingly very long moment short, I decided that we could walk. Again, Andries was much more prepared than I was and was perfectly willing to do whatever was necessary. As we walked, we saw more donkey carts led by older boys and men, and garbage organised in mountain-high piles of plastic, of tin, of glass, and of cloth. Various colours and odours filled the air smoke from the burning of trash and from mothers cooking meals, as well as from men puffing on cigarettes and pipes. Whilst we walked, Sharif explained that each and every night the Zabbaleen collect at least one-third of the garbage of the nearly 20 million people who live in Cairo; if you live in Cairo, you put out your garbage and trash at night, and by morning it will have been picked up by the Zabbaleen. Once the trash is delivered to the mountain homes, women and children rummage through the rubbish to sort and recycle. This must be done by hand. Sharp objects cause wounds that result in serious infections. The infant mortality rate in this city is much higher than in other parts of Cairo and in all of Egypt; life expectancy is far lower than for the rest of Egypt. Hepatitis runs rampant. The Zabbaleen obviously are outcasts from the rest of society and many call them a 'caste' of their own - the lowest caste, obviously. ${ }^{4}$

Sharif, who volunteers on a regular basis in the City of

4.According to Benedict Faccini (1999:5), the Zabbaleen peasant farmers had been streaming into Mokattam from Upper Egypt [southern Egypt] since the 1940s, fleeing bad harvests and drought and recreating a rural world with its traditions and rules inside Cairo. But, according to Kees Ulsman, (1997:1), the government ordered the garbage collectors and their trash removed in the 1970s 'from a lush, green area of Imbaba near Cairo's center to Muqattam's rocky desert [where] many perished'. 
Garbage Pickers, told us that, until recently, the Zabbaleen used only donkey-carts, but had now purchased a few large garbage trucks to supplement the carts - the ones that had hemmed us in. Human-rights groups had begun to put pressure on the city of Cairo because of the squalor in which the Zabbaleen were living. So, in 2003, one Italian and two Spanish trash collecting companies were hired to do part of the job and were, in turn, supposed to hire the Zabbaleen to work for them. Cairo authorities did not think through the ramifications of their actions because the Zabbaleen went on strike and refused to be hired by the Spanish and Italian companies, so those companies were let go and the Zabbaleen were left to collect all of the garbage again.

Sharif, Andries and I slogged our way through the narrow city streets for several blocks and saw preschool children, including babies, and goats playing together in three-storyhigh garbage piles. We saw men, women, and children wearing filthy rags whilst the 'freshly' laundered clothes hanging out from homes, made of cardboard and metal collected from the garbage, were in a far worse condition than anything I had seen in any of the poverty-stricken rural areas of African countries I had visited. If you have not already gathered as much, the people live in the trash. I repeat: their homes are built in - and out of - the garbage. According to Faccini (1999), these:

houses serve as both sorting points for waste and accommodation. Each family has its own particular skills, some families are experts in recycling plastic bottles, others deal in metal, others still have the grim task of sorting through hospital waste.

(Faccini 1999:06)

It turned out to be the one and only time that I was fearful for my well-being on the entire continent of Africa: I had asked ahead of time if I could take pictures and was assured by the 'authority' whom Sharif consulted that it was perfectly okay. However, as I was about to snap the picture of the babies playing in the trash pile with the goats, the mother of one of them lunged at me and Sharif had to step between us quickly and assure her that I would put my camera away until we had left the city. And I did! It probably also means that Sharif was much more wary and on the lookout for such happenings than I was aware of.

All of a sudden (quite literally), we turned a corner into a clearing that was spic and span; a spotless road led to many, many beautifully adorned Coptic cave churches, resplendent with carvings on the limestone walls, inside and outside. The stench had left the air and all the horrendous noises were silenced. I caught my breath (once again); we stomped the sludge from off our shoes, and proceeded to the Monastery of St Simon the Tanner, which actually houses seven absolutely gorgeous churches and chapels, all built in the caves. The Cathedral of the Virgin Mary and St Simon forms the main church and seats approximately 10000 people. The history of the church, according to the Copts, is that an educated and open-minded caliph by the name of Al Muizz enjoyed inviting religious leaders from diverse traditions for conversation - civil debates, as it were. At one of those meetings in this 10th-century setting, the discussion between the Coptic Pope Abram and one of his Jewish friends, Jacob Ibn Killis, became a bit heated and the pope was winning. The story reaches a climax when Ibn Killis challenges the pope with the New Testament text concerning Jesus, saying 'If you have faith as small as a mustard seed, you can say to the mountain, move from here to there, and it will move, nothing will be impossible for you' (Mt 17:20). The caliph rose to the occasion and, because he wanted to remove the mountain that was spoiling his view anyway, chose a man by the name of Simon to move the Mokattam Mountain. Simon prayed and fasted for three days, after which an earthquake moved the mountain. Simon, who was subsequently canonised, was never seen again, but the monastery bearing his name has an educational centre, a kindergarten and a school for the hearing impaired, and offers literacy and vocational courses. I cannot emphasise enough how clean everything was! I also have to admit a terrible failing on my part: Andries and Sharif explored another cave church, but I sat at a table in one of the patios in a beautiful (and clean) clearing in the mountains. Two women and their children invited me through gestures to join them in their noontime meal (I know no Arabic and they knew no English). I allowed my body to join them, but I refrained from eating the food they offered. The sin of refusing hospitality surely must be unforgivable.

In addition to the phenomenon of a City of Garbage Pickers - others, for example, are found in Mexico, India, China and in South American countries - three more things boggle my mind. Firstly, according to Sharif, the people who live in the City of Garbage Pickers are wealthy - I have yet to manage to wrap my brain around the concept of wealth not buying health and education - and I'm not convinced that Sharif is correct, but I cannot locate anyone who 'knows'. Secondly, environmental groups around the world have defended, commended, and even given awards to the Zabbaleen for their model of environment friendliness, in particular for the role they play in recycling garbage. Meanwhile, I have read hardly anything about environmental groups actually visiting the inhabitants of the Muqattam Mountains in any of the websites and sources I have searched since visiting the City of Garbage Pickers, but perhaps such groups have and I am judging where I ought not to be judging. Lastly, according to Sharif, no one leaves the city. High-school-aged children, especially boys, do get out of the city and know what the world outside is like. Yet, they choose to stay within the community and culture. Sharif rehearses the argument that some of the Zabbaleen themselves put forward: that it is a nasty job, but the entire family is involved in the business. The fathers and sons collect the trash whilst the wives, daughters, and younger children sort and recycle the garbage; everyone then sells it. And, the more children a couple has, the more help they have in the family business.

Sharif, Andries and I headed back through the city on foot because Sharif could not argue a taxi driver into picking us up until we had reached the entrance. We walked without incident - my camera was well hidden and out of 
temptation's sight. When we had returned to Cairo, I asked several Egyptians about the City of Garbage Pickers, but they did not want to talk about it; some even were angry because I asked. Upon returning home to the US, I asked Bishop Bruce Ough of the West Ohio Conference of the United Methodist Church if he had ever heard of the City of Garbage Pickers. He responded that he had. In fact, the United Methodist Church had tried to help at one point, but had been asked to leave. ${ }^{5}$ The City of Garbage Pickers truly is beyond the imagination or the telling of it. In the end, it was quite incredible to consider the extremes of the spectrum; at one end, the grandeur of Egypt's history and present-day culture and, at the other end, the stench of modern-day poverty in the caves where, as a gospel writer tells us, the Holy Family once lived.

Incidentally, concerning those sandals that the students thought I should replace with boots - I washed them in the shower when I got back to my dorm room, but I could not make myself put them back on. I left them for the Zabbaleen to pick up with the morning's garbage!

\section{Coptic Christianity and women}

This is my second source of puzzlement. Andries and I were both intrigued by paintings based on stories about Jesus and women that we saw in the cave churches, especially in St Simon the Tanner Coptic Church, when we walked along with Sharif. The story of the Nativity, of course, is a natural choice for the Copts; they, after all, live in the story's original setting in Egypt (Mt 2) and are probably the descendants of the very first Christian communities. There are a number of carved and painted depictions of women-centred stories in the Church, which include at least three Marys: the mother of Jesus, the sister of Jesus, and the sister of Lazarus. Mary, the sister of Jesus, comes to us through the Gospel of Philip (59.5-15):

There were three who always walked with the Lord: Mary his mother and her sister and Magdalene, the one who was called his companion. His sister and his mother and his companion were each a Mary.

Jorunn Jacobsen Buckley (1988) argues as follows:

The adverb 'always' suggests that the woman (sic) may have been closer to and more ardent followers of Jesus than were the other (male) disciples. Inconsistently, the second Mary is called the sister of Jesus' mother, and then his sister, but this might be a scribal error.According to J.-E. Menard, she is Mary-Salome of Matt. 28:56 [sic], an important gnostic figure. 'Companion' for Mary Magdalene can mean 'spouse' or 'wife.'

(Buckley 1988:214-215)

In addition to her being mentioned in Mark's gospel, Salome can be found in the Gospel of the Egyptians. Perhaps that makes sense, since the Coptic Church claims Mark as the first preacher in Egypt.

But Mary of Magdala is 'missing' from the cave churches and, for that matter and as far as I could tell, from Egypt. In fact,

5.In trying to find hope in a hopeless situation (according to me), I accessed an article by Yasmine Kandil (2005), a young woman from Cairo who was a student in Victoria, by Yasmine Kandil (2005), a young woman from Cairo who was a student in Victoria,
British Columbia. For her personal account, see 'Cultivating fresh hope: Director takes up cause for "poorest of the poor"' in Times Colonist. when Andries and I had earlier travelled to St Catherine's Monastery in the Sinai, we noticed that Mary of Magdala was conspicuously absent. The truth of the matter is that I could not find Mary of Magdala anywhere in Egypt (see Carroll 1986:132). ${ }^{6}$ When I returned home, I contacted Prof. Karen King at Harvard University to see why this might be the case and she was also puzzled; Dr David Grafton, our host professor at the Evangelical Seminary in Cairo, took on the question, but he also could not explain this absence, or point to any presence of Mary Magdala in Egypt. The issue is particularly intriguing because of the Coptic text known as the Gospel of Mary. In the secondary literature, I have found only one reference, which coupled her with Salome, whom I have mentioned above. Jill Kamil (2002) puts it as follows:

Often, when accompanying visitors around Egypt, I have been asked how Egyptians, with a 3,000-year ancient history, could suddenly have abandoned their traditional beliefs and adopted Christianity. In fact, when Pharaonic temples were converted into churches, their walls plastered over and repainted with images propagating the new faith, it was not difficult for them to adopt artistic themes from their own mythology for an interpretation of Christian beliefs. Egypt's goddess Isis, frequently represented with the ideogram for a throne on her head, could be transformed, with slight modification, into the Virgin Mary enthroned. Mary Magdalene and Salome preparing to anoint with sweet spices the body of Christ after he was taken from the Cross repeated a ritual from Egyptian mythology - the goddesses Isis and Nephthys cleaning and lamenting over the body of Osiris in the myth. The ancient Egyptians magnified the heroic and beneficent qualities of their gods and related their deeds in numerous legends. Likewise, local martyrs, saints, patriarchs, monks and hermits (some honoured throughout the Christian world) received special distinction in Egypt. Their relics continue to be the focus of worship, their images indispensable adornments of churches.

(Kamil 2002:149)

Kamil (2002) also highlights Saint Mary the Egyptian, an interesting possibility for paralleling what was developed as the tradition for Mary of Magdala, but not cited as such:

Saint Mary of Egypt was a prostitute of Alexandria in the middle of the fourth century who, having joined a group of pilgrims to Jerusalem for the Feast of the Exaltation of the Cross in order to find customers, was suddenly filled with remorse for her sinful life, prayed and begged forgiveness. She chose to live a pious life in isolation in repentance in a lonely place beyond the river Jordan. There she lived for many years, died and was buried. A feast in her honour is celebrated by the Eastern Churches on 1 April and by the Western on 2 April.

(Kamil 2002:278)

This also brings to the fore the role of women in Coptic Christianity, where it has fared no better than in some of our western strands; according to Otto F.A. Meinardus (2002), concerning:

widespread ordinations of women as pastors and bishops in Western churches since the middle of the twentieth century, Pope Shenuda III has repeatedly declared the irrevocable and incontestable teaching of the church, which prohibits women from carrying out priestly offices.

(Meinardus 2002:45)

6.One exception may have been a garment ornament which could be picturing Mary Magdalene, 'a popular figure for Copts because of her later life spent as a hermit' (Carroll 1986:132). 
This declaration is reputedly based on 1 Corinthians 14:3334, 1 Timothy 2:12, Eve's original sin, and women's monthly menses (Van Doorn-Harder 1995:11-12). In other words, most women in most religious traditions are considered to be unclean during their reproductive years - even today. Meinardus (2002:46-50) discusses the difficulties faced by Coptic women who want to live out their beliefs, and highlights 'The Women Monks', 'The Virgins', and 'The Mothers' in the history of Coptic Christianity.

In modern times, three types of religious women feature in the Coptic Church, according to Pieternella van DoornHarder (1995): the traditional contemplative nuns, the newly-developed community of active nuns, and the socalled consecrated women, whose position reflects a type of deaconess. Van Doorn-Harder (1995:10) presents a fascinating discussion on hierarchies that includes Louis Dumont's argument that women in the western world can in no way conceptualise a hierarchy that is not 'intrinsically unfair'. In contrast, Van Doorn-Harder (1995; cf. Afaf Lutfi al-Sayyid Marsot 1980:268-269; Willy Jansen 1987; Lila AbuLughod 1989, 1999) argues as follows:

Studies about women in the Muslim world have shown that women of different social strata deal with the hierarchic system in which they find themselves by developing their own activities, discourse, and strategies to evade, avoid, or ignore the system. These women have developed strategies to support their position and to exercise indirect influence, especially in the field of religion and the supernatural. In this process they form their own extrahierarchic or counterhierarchic systems.

(Van Doorn-Harder 1995:10)

According to Van Doorn-Harder (1995:11), there are two levels to the ecclesiastical hierarchy in modern Coptic Christianity: ordained clergy, from whom women are excluded, and monks who are not ordained, which parallels the nuns. There is a 'social hierarchy' as well as a 'spiritual or divine hierarchy' (Van Doorn-Harder 1995:12-14).

Coptic texts, Gnosticism and the Coptic Church cannot be conflated, of course. Birger A. Pearson (1990) elucidates the problem:

[It is] evident that Gnosticism played an important role in the development of Christianity in Egypt ... Indeed, we shall have to consider whether or not Egyptian Christianity, from its very beginnings in Alexandria, was essentially a Gnostic and thus, from a later perspective, heretical form of the Christian religion. These questions are not at all easy to decide; ... the origins of Egyptian Christianity are shrouded in obscurity, owing to a dearth of reliable evidence. As a result, scholarly opinion has varied greatly as to the sources and origins of Egyptian Christianity, and the nature and makeup of the Egyptian church in its earliest stages.

(Pearson 1990:195)

Pearson (1990:196) discusses the conclusion, arrived at by Walter Bauer (1971) in his book, Orthodoxy and heresy in earliest Christianity, that 'the earliest form of Christianity in Egypt was not orthodox but heretical, specifically, Gnostic'. He concludes that Bauer was 'wrong on the question of the origins of Christianity in Egypt, and ... probably wrong in his assessment of the relative numerical strengths of the non-
Gnostic and Gnostic Christians there' (Pearson 1990:209). Karen L. King (2003:8), on the other hand, writes: 'Since Coptic script was used almost exclusively by Christians in Egypt, we can assume that Egyptian Christians were the ones who translated and preserved the Gospel of Mary.' But she is not so quick to say that the Gospel of Mary is Gnostic either (King 2003:170-171).

\section{Conclusion}

I have come to no conclusions. I remain confused and puzzled about the issues of poverty and women. One can do the necessary research and find all kinds of prescriptions and justifications for the status and role of the poor and of women; one can also find ways to be the ostrich with its head in the sand. And whilst poverty itself is not to be congratulated, the poverty-stricken are. One of my grandmothers lived in poverty, but we grandchildren were oblivious to her status because she was so incredibly generous with what resources she had. In fact, it was not until I became involved in the rural areas of Africa and with the homeless in California that I realised that my grandmother was, by definition, poor. She died in 1974 without having had running water, but we grandchildren fought over who got to pump the water outside and then over who got the first Saturday night bath in the steel tub in the middle of the kitchen floor next to the cooking stove. She enjoyed thinking beyond her own rural Wisconsin village and was thrilled when second-born Thad a bi-racial baby from Milwaukee - arrived in our family. As I think about it, Grandma embodied the poor - an independent, enlightened woman who knew how to take care of all her own physical needs with some ingenuity and a whole lot of hard work and determination - and shared whatever resources she did have. She should have been congratulated; I know she felt blessed. ${ }^{7}$ And this is where all poor and otherwise oppressed people should be congratulated; in all of my travels and in my preference to be with the poor, I have never wanted for a single thing - poverty-stricken people are by far the most generous in the entire cosmos.

The exegesis of a biblical text that deals with the oppressed, specifically with the poor and with women is always fascinating. It is right to travel to the destitute areas of our own worlds and beyond and to describe their circumstances; it is right to teach and profess against inequality. But one can also do what Andries does: travel, write, teach, profess - and do something about it. I will always be grateful to him for opening up the world and its riches to me. He personifies radical inclusivity. We wait with bated breath and hope for everyone in Egypt that the peoples' protests begun in January 2011 in Cairo's Tahrir Square will lead to the fruition of such profundity.

\section{References}

Abu-Lughod, L., [1986] 1999, Veiled sentiments: Honor and poetry in a Bedouin society, rev. edn., University of California Press, Berkeley.

Abu-Lughod, L., 1989, 'Zones of theory in the anthropology of the Arab world', Annual Review of Anthropology 18, 267-306. doi:10.1146/annurev.an.18.100189.001411.

7.Daryl Schmidt argued, at the Jesus Seminar, that beatitude embodies more of a sense of congratulation than blessing. Hence, the Scholars' Version reads, 'Congratulations, you poor! God's domain belongs to you' (Lk 6:20). Cf. The Five Gospels, p. 290 
Bauer, W., [1934] 1971, Orthodoxy and heresy in earliest Christianity, transl. R.A. Kraft \& G. Kroedel, Fortress Press, Philadelphia, PA.

Buckley, J.J., 1988, 'The Holy Spirit is a double name', in K.L. King (ed.), Images of the feminine in Gnosticism, pp. 211-227, Fortress Press, Philadelphia, PA.

Carroll, D.L., 1986. Looms and textiles of the Copts: First millennium Egyptian textiles in the Carl Austin Rietz Collection of the California Academy of Sciences, California Academy of Sciences, San Francisco, CA.

El-Beltagui, M., n.d., 'The Holy Family in Egypt', viewed 15 June 2010, from http:// www.touregypt.net/holyfamily1.htm

Faccini, B., 1999, “From Garbage to Gold in Cairo," UNESCO Sources 108, pp. 5-7.

Funk, Hoover, and The Jesus Seminar, 1993, The Five Gospels: What Did Jesus Really Say?, Macmillan Publishing, New York.

Hulsman, K., 1997, 'Poverty: Trash Collector Church Salvages Cairo Village', 41(9).

Jackson, G., 2004a, 'The Jesus Seminar in Africa', in The Historical Jesus goes to church, pp. 81-90, Polebridge Press, Santa Rosa, CA

Jackson, G., 2004b, 'Rebel soldiers as Good Samaritans: New Testament parables in an African context', HTS Theological Studies 60(1\&2), 239-247.

Jackson, G., 2008, 'From Hippo to Hippos: Being on the edge of smash in Africa', in C.W. Hedrick (ed), When faith meets reason: Religion scholars reflect on their spiritual journeys, pp. 1-11, Polebridge Press, Santa Rosa, CA.
Jansen, W., 1987, Women without men: Gender and marginality in an Algerian town E.J. Brill, Leiden.

Kamil, J., 2002, Christianity in the land of the Pharaohs: The Coptic Orthodox Church, Routledge, London.

Kandil, Y., 2005, 'Cultivating fresh hope: Director takes up cause for "poorest of the poor"', Times Colonist, 24 February, n.p.

King, K.L., 2003, The Gospel of Mary of Magdala: Jesus and the first woman apostle, Polebridge, Santa Rosa, CA.

Lutfi al-Sayyid Marsot, Afaf, 1980, 'The revolutionary gentle-women', in L. Beck \& N. Keddie (eds.), Women in the Muslim world, pp. 268-269, Harvard University Press, Cambridge, MA

Meinardus, O.F.A, 2002, Coptic saints and pilgrimages, American University in Cairo Press, Cairo.

Pearson, B.A., 1990, Gnosticism, Judaism, and Egyptian Christianity, Fortress Press, Minneapolis, MN

Van Doorn-Harder, P., 1995, Contemporary Coptic nuns, University of South Carolina Press, Columbia, SC. 